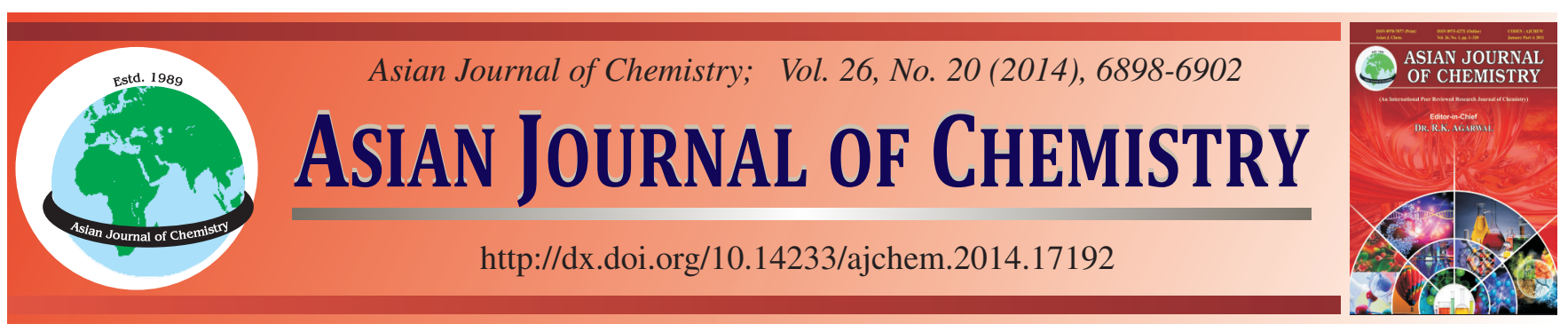

\title{
Biochemical Changes Concerning the Effect of Synthetic Chocolate Flavor and Colour in Albino Rats
}

\author{
G.E. Eldesoky ${ }^{1,2, *}$, Z.A. Alothman ${ }^{1}$ and M. NAUSHAD ${ }^{1}$
}

${ }^{1}$ Department of Chemistry, Faculty of Science, King Saud University, P.O. Box 2455, Riyadh 11451, Saudi Arabia

${ }^{2}$ Department of Biochemistry, College of Agriculture, Cairo University, Giza, Egypt

*Corresponding author: E-mail: geldesoky@ksu.edu.sa

\begin{abstract}
Colors in foods are an integral part of our culture and are also indispensable to modern day consumer. This study was carried out to evaluate the effect of synthetic food colour as well as synthetic food flavor and its mixture of brown chocolate on some biochemical indices including, glutamate oxalacatate transaminase (GOT) and glutamate pyruvate transaminase (GPT) enzyme activities, total protein, lipid profile (total cholesterol and total triglycerides) in liver and blood of brown chocolate treated rats, also, determine blood glucose, hemoglobin, bilirubin and thyroid hormones $\left(\mathrm{T}_{4}\right.$ and $\left.\mathrm{T}_{3}\right)$ in blood as well as liver glycogen of food additives treated rats. The results showed that blood sugar content of rats fed on synthetic food additive was elevated, which was accompanied by reduction in liver glycogen compared to the control rats. However, these treatments decreased total lipids and total cholesterol in both blood and liver. Contrary, transaminases (GOT and GPT) activities and protein level were enhanced in blood and liver by synthetic colour and flavor of chocolate. Hemoglobin, bilirubin and thyroid hormones $\left(\mathrm{I}_{4}\right.$ and $\left.\mathrm{I}_{3}\right)$ were also elevated under the same treatments relative to the control. All these alteration were observed much greater by chocolate mixture than by chocolate flavor or colour. Also, liver was more affected than blood.
\end{abstract}

Keywords: Synthetic food colour, Enzymes, Rat, Chocolate.

\section{INTRODUCTION}

Food additives are vital in today's nutritious foods. Food additives facilitate diversity among safe and tasty foods for human consumption and make available an array of foods without the troubles of daily shopping Food colouring agents are classified as natural colouring products and are traditionally used in food, drugs and cosmetics. The first dyes used at an industrial scale for cosmetic purposes were based on ashes from burned minerals and plants ${ }^{1}$. Food colourants include either dyes or pigments. Pigments can be either organic or inorganic compounds, which are largely insoluble in the solutions in which they are incorporated. In contrast, dyes dissolve readily in food products during the stirring process, consequently losing their crystalline structure ${ }^{2}$ Numerous foodcolouring dyes have been excluded from the list of approved food colours due to the carcinogenic and mutagenic activities of these substances. Some of the synthetic colouring additives cause severe tension to the consumer as general health for example tartazine E102 and chocolate brown as synthetic colouring agents caused DNA liver and kidney damage as detected by comet assay ${ }^{3}$. Synthetic colour for example chocolate colour agents decrease rat body weight, serum cholesterol and HDL cholesterol and increase liver enzyme ${ }^{4,5}$ Food colourants (amaranth, erythrosine and tartrazine) had a toxic potential to human lymphocytes in vitro and seems that they bind directly to DNA ${ }^{6}$. Tartrazine not only causes changes in hepatic and renal parameter but also their effect become more risk at higher doses because it can induce oxidative stress by formation of free radical. Synthetic colourants are classified as follows: (i) azo compounds, such as sunset yellow and tartrazine; (ii) chinophthalon derivatives of quinoline yellow; (iii) the triarylmethane group; (iv) xanthenes, such as erythrosine; and (v) indigo colourants. Approximately 800,000 tons of dyes are produced per year worldwide, of which 60$70 \%$ are azo dyes. An estimated $10-15 \%$ of these dyes pollute the environment during industrial manufacturing ${ }^{7}$.

Currently, only nine approved synthetic colour additives are used in cosmetics, foods and drugs in the United States of America $^{8}$. The admissible daily intake (ADI) is employed as a guideline to control the amount of consumed dyes, thus limiting their bioaccumulation in the human body ${ }^{9}$. Colour is an important characteristic and selection criterion for food choice. Synthetic colour in basic food stuffs such as: bread 
cereals, cheese and milk products, fried fish and meat products, ice cream, juices, sweets, sugar toys, jams and jellies ${ }^{10,11}$. The importance of food colour has been recently highlighted and the preferential selection of colour may change among populations as a function of time ${ }^{12}$. With the increasing awareness of possible health hazards associated with such use, more attention has been focused recently on biological activity of these compounds. The absence of data on the pharmacokinetics and metabolism affected by the synthetic flavors or colourants and the potential formation of toxic metabolites by reductive cleavage of the unsaturated or azo linkage has caused many international agencies to require metabolic and toxic-kinetic studies in different species ${ }^{13}$. Further investigations were carried out on synthetic food colourants but not on synthetic food flavors evaluate the acceptability of these compounds as food additives for human and animal feeding. It should be emphasized that literature background had poor available data about the present items with exception of some work by Bawazir ${ }^{14}$ and Elhkim et al. ${ }^{15}$.

This study was carried out to evaluate the effect of synthetic food flavoring and colourant (chocolate flavor and chocolate brown F8) on the blood glucose, $\mathrm{T}_{4}, \mathrm{~T}_{3}$. Total hemoglobin, bilirubin and liver glycogen as well as Total lipid, Total cholesterol, protein and treansminases (GOT and GPT) activities of blood and liver of the additives treated rats.

\section{EXPERIMENTAL}

Synthetic food flavoring (chocolate flavor) and food colourants (chocolate brown F8) were provided by Aromas' Co. (Egypt). The mixture of chocolate flavor and colour was prepared by mixing chocolate flavor and chocolate brown FB in a ratio of $1: 1(\mathrm{w} / \mathrm{w})$.

A total of 40 adult albino rats were kept under normal healthy laboratory conditions and fed normal standard diet according to lanepetter and pearson ${ }^{16}$. The rats were divided into 4 groups. The first group (10 rats) was kept as control and fed on flavor or colourant samples-free diets. The second and third groups (each of 10 rats) were orally administrated a daily dose $(4 \mathrm{~g} / \mathrm{kg}$ diet $)$ of only one of the chocolate colour and flavor. The fourth group (10 rats) was orally administrated a daily dose ( $8 \mathrm{~g} / \mathrm{kg}$ diet) of the mixture samples for a period of 30 days, short term treatment ${ }^{17}$.
The experimental animals were killed by decapitation at the end of a month period, then blood samples subjected to plasma separation for estimation of glucose, $T_{4}, T_{3}$, total hemoglobin, total bilirubin, total lipid and total cholesterol as well as GOT and GPT activities. Liver of each was also dissected out and chilled for determination of glycogen, total lipid, total cholesterol, protein and transaminases activity.

Serum glucose was determined according to Astoor and king ${ }^{18}$ total thyroxin $\left(\mathrm{T}_{4}\right)$ was measured by radio immunoassay procedure by Premachandra and Ibrahim ${ }^{19}$ and triiodothyroxin $\left(\mathrm{T}_{3}\right)$ was measured by double antibody technique as described by Chopra et al. ${ }^{20}$. Total lipids in plasma and liver tissue were determined according to Joseph et $_{\text {al. }}{ }^{21}$. Total cholesterol in plasma and liver tissue was determined according to Chaurchami et $a .^{22}$. Glycogen was determined in the rat liver according to the method of Rerup and Lundguist ${ }^{23}$. Plasma total bilirubin was estimated according to Jendrassik and $\mathrm{Crof}^{24}$ method. Total hemoglobin was determined according to Dacie and Lewis ${ }^{25}$ method. Total soluble proteins of plasma and liver tissue were carried out according to the method of Henry ${ }^{26}$. Glutamateoxalacatate transaminase (GOT) and glutamate pyruvate transaminase (GPT) were determined in plasma and liver tissue according to Ritman and Frankel ${ }^{27}$. Statistical methods were carried out according to Snedecor and Cochran ${ }^{28}$.

\section{RESULTS AND DISCUSSION}

Metabolic changes in blood and liver of albino rate administrated chocolate flavor, chocolate brown FB and chocolate flavour and colour mixture along one month period are recorded in Tables 1,2 and 3. The results obtained involving blood and liver transaminases activity and protein contents are found in Table- 1 . The data demonstrated that the three treatments of synthetic food additives significantly $(\mathrm{P}<0.05)$ elevated the activities of both GOT and GPT either in blood or liver. However the magnitude of difference between control and each of the three treatments was small for GPT, which a remarkable increase in blood and liver of rats subjected to chocolate flavor and colour mixture, but the minimal value was indicated in case of rats subjected to chocolate flavor. In connection, blood and liver total soluble protein was significantly $(\mathrm{P}<0.05)$ increased throughout the course of each treatment relative to control. The total soluble protein content

\begin{tabular}{|c|c|c|c|c|c|c|c|}
\hline \multicolumn{8}{|c|}{$\begin{array}{l}\text { TABLE-1 } \\
\text { EFFECT OF SHORT-TERM OF CHOCOLATE FLAVOR AND CHOCOLATE COLOURANT ON TRANSAMINASES } \\
\text { [GLUTAMATE OXALACATATE TRANSAMINASE (GOT) AND GLUTAMATE PYRUVATE TRANSAMINASE (GPT)] } \\
\text { ACTIVITY AND PROTEIN CONTENT IN BLOOD AND LIVER OF RAT }\end{array}$} \\
\hline & Treatment & GOT U (mL) & $(\%)$ & GPT U (mL) & $(\%)$ & $\mathrm{g} / 100 \mathrm{~mL}$ & Protein \\
\hline \multirow{4}{*}{ Blood } & Control & $32.01 \pm 3.11$ & 100 & $13.50 \pm 1.33$ & 100 & $7.02 \pm 0.73$ & 100 \\
\hline & Chocolate flavor & $41.61 \pm 4.30$ & 130 & $15.66 \pm 1.49$ & 116 & $7.72 \pm 0.78$ & 110 \\
\hline & Chocolate brown FB & $43.53 \pm 4.13$ & 136 & $15.80 \pm 1.51$ & 117 & $8.00 \pm 0.73$ & 114 \\
\hline & Chocolate flavor and colour mixture & $45.13 \pm 4.52$ & 141 & $16.61 \pm 1.49$ & 123 & $8.35 \pm 0.81$ & 119 \\
\hline & & $\mathrm{U}(\mathrm{g})$ & & $\mathrm{U}(\mathrm{g})$ & & $\mathrm{g} / 100 \mathrm{~g}$ & \\
\hline \multirow{4}{*}{ Liver } & Control & $115.24 \pm 11.11$ & 100 & $39.69 \pm 4.00$ & 100 & $20.03 \pm 2.11$ & 100 \\
\hline & Chocolate flavor & $137.14 \pm 12.77$ & 119 & $45.64 \pm 4.61$ & 115 & $24.04 \pm 2.30$ & 120 \\
\hline & Chocolate brown FB & $142.90 \pm 14.32$ & 124 & $46.44 \pm 4.37$ & 117 & $25.64 \pm 2.61$ & 128 \\
\hline & Chocolate flavor and colour mixture & $146.35 \pm 15.00$ & 127 & $47.63 \pm 5.00$ & 120 & $25.84 \pm 2.62$ & 134 \\
\hline
\end{tabular}




\begin{tabular}{|c|c|c|c|c|c|c|c|}
\hline \multicolumn{8}{|c|}{$\begin{array}{l}\text { TABLE-2 } \\
\text { EFFECT OF SHORT-TERM TREATMENT OF CHOCOLATE FLAVOR AND CHOCOLATE COLORANT ON TOTAL LIPID } \\
\text { AND CHOLESTEROL OF BLOOD AND LIVER AS WELL AS BLOOD GLUCOSE AND LIVER GLYCOGEN IN RATS }\end{array}$} \\
\hline & Treatment & $\begin{array}{c}\text { Total lipid } \\
(\mathrm{mg} / 100 \mathrm{~mL})\end{array}$ & $(\%)$ & $\begin{array}{l}\text { Total cholesterol } \\
(\mathrm{mg} / 100 \mathrm{~mL})\end{array}$ & $(\%)$ & Glucose (mg/100 mL) & $(\%)$ \\
\hline \multirow{4}{*}{ Blood } & Control & $820 \pm 82$ & 100 & $122 \pm 13$ & 100 & $101 \pm 10$ & 100 \\
\hline & Chocolate flavor & $615 \pm 65$ & 75 & $104 \pm 10$ & 85 & $119 \pm 19$ & 118 \\
\hline & Chocolate flavor and colour mixture & $533 \pm 56$ & 65 & $88 \pm 9$ & 72 & $141 \pm 14$ & 140 \\
\hline & & $\mathrm{gm} / 100 \mathrm{~g}$ & $(\%)$ & $\mathrm{mg} / 100 \mathrm{~g}$ & $(\%)$ & Glycogen $(\mathrm{mg} / 100 \mathrm{~g})$ & \\
\hline \multirow{4}{*}{ Liver } & Control & $3.64 \pm 0.40$ & 100 & $262 \pm 27$ & 100 & $5.30 \pm 0.52$ & 100 \\
\hline & Chocolate flavor & $3.02 \pm 0.28$ & 83 & $183 \pm 17$ & 70 & $4.08 \pm 0.39$ & 77 \\
\hline & Chocolate brown FB & $2.91 \pm 0.30$ & 80 & $168 \pm 17$ & 64 & $3.45 \pm 0.32$ & 65 \\
\hline & Chocolate flavor and colour mixture & $2.69 \pm 0.29$ & 74 & $157 \pm 16$ & 60 & $3.07 \pm 0.30$ & 58 \\
\hline
\end{tabular}

\begin{tabular}{|c|c|c|c|c|}
\hline \multicolumn{5}{|c|}{$\begin{array}{l}\text { TABLE-3 } \\
\text { EFFECT OF SHORT-TERM TREATMENT OF CHOCOLATE FLAVOR AND CHOCOLATE } \\
\text { COLORANT ON TOTAL HEMOGLOBIN, TOTAL BILIRUBIN, } \mathrm{T}_{4} \text { AND T } \text { T }_{3} \text { OF RAT BLOOD }\end{array}$} \\
\hline Treatment & Total hemoglobin $(\mathrm{mg} / 100 \mathrm{~mL})$ & $(\%)$ & Total bilirubin $(\mathrm{mg} / 100 \mathrm{~mL})$ & $(\%)$ \\
\hline Control & $15.10 \pm 1.48$ & 100 & $1.00 \pm 0.11$ & 100 \\
\hline Chocolate flavor & $15.25 \pm 1.37$ & 101 & $1.40 \pm 0.12$ & 140 \\
\hline Chocolate brown FB & $15.70 \pm 1.40$ & 104 & $1.85 \pm 0.17$ & 185 \\
\hline Chocolate flavor and colour mixture & $15.90 \pm 1.61$ & 105 & $2.00 \pm 0.18$ & 200 \\
\hline Treatment & $\mathrm{T}_{4}(\mu \mathrm{g} / 100 \mathrm{~mL})$ & $(\%)$ & $\mathrm{T}_{3}(\mu \mathrm{g} / 100 \mathrm{~mL})$ & $(\%)$ \\
\hline Control & $4.20 \pm 0.43$ & 100 & $90.00 \pm 10.00$ & 100 \\
\hline Chocolate flavor & $1.54 \pm 0.40$ & 108 & $99.00 \pm 10.00$ & 110 \\
\hline Chocolate brown FB & $4.87 \pm 0.50$ & 115 & $104.40 \pm 10.17$ & 116 \\
\hline Chocolate flavor and color mixture & $4.96 \pm 0.43$ & 118 & $108.00 \pm 10.91$ & 120 \\
\hline
\end{tabular}

in liver was affected more than in blood of inducted rats. Furthermore, rats inducted chocolate mixture had the higher effect on blood or liver protein than the both either treatments. It can be concluded that all food additives treatments significantly enhanced the transaminases activity and the protein content in blood and liver of inducted rats.

These findings suggested that food additives might disturb the level of blood or liver total soluble protein of inducted rats by stimulation the protein biosynthesis ${ }^{29}$ to produce specific enzymes for destruction of detoxication processes of synthetic food additives and also by stimulation of certain endocrine gland activity for excretion the hormones which regulated protein metabolism ${ }^{30}$. The present results were agreed with those of Abdel-Rahim et al..$^{30}$. They found that the food additives (flavor and colourant) increased protein content in blood and liver of rats and also GOT and GPT activity. The stimulation of both GOT activity of blood and liver was attributed to food "flavor and colourant. Generally plasma GOT and GPT are considered to be sensitive indicator of liver function and their activity increase in the condition that produce hepatic dysfunction ${ }^{31}$. However GPT is more specific for liver damage than $\mathrm{GOT}^{32}$. In the same respect, Bawazir ${ }^{14}$, showed that there were significant $(\mathrm{P}<0.001)$ elevations in the level of aspartate aminotransferase (AST) and alkaline phosphatase in the serum of male albino rat treated chocolate brown HT (200 mg/kg b. wt.) for 4 weeks. This increase was 444.46 and $113.19 \%$, respectively when compared with the control. Also, significant $(\mathrm{P}<0.05)$ increase in the level of alanine aminotransferase (ALT) in the serum of male albino rat was noticed.
A significant increase in serum ALT and AST may be attributed those change in liver function to be hepatocellular impairment level of intracellular enzymes into the blood ${ }^{33}$. The release of a normally high level of specific tissue enzymes into blood stream is dependent on both the degree and type of damage exerted by the toxic compound administration ${ }^{34,35}$. These results are in accordance with data reported by Mekkawy et al. ${ }^{36}$ and Amin et $a l .{ }^{37}$. They indicated that rats which consumed high dose synthetic colour (Tartarzine, Carmoisin, sunset yellow and fast green) showed a significant increase in serum ALT and AST when compared to control rats . From the inspection of the data presented in Table-2, it is clear that chocolate flavor, chocolate brown FB chocolate mixture elevated the blood sugar relative to control. Contrary, a remarkable decrease in liver glycogen was observed. However, chocolate mixture was more effective than chocolate flavor or chocolate colourant alone. Meanwhile, chocolate flavor induced slight but significant effect particularly by the short term treatment with comparing to the chocolate brown FB or chocolate mixture effects. In addition the findings of blood sugar and liver glycogen may be due to the stimulation of enzymes activity of glycogen breakdown as well as glycolytic process in relation with the experimental condition ${ }^{38}$. Subsequently this reduction of liver glycogen contents may be due to the secretion of thyroid hormones (results of the present work). These hormones activate the AMP formation and hence exhibit the conversion of phosphorylase ${ }^{39}$. This might be considering as a protective system in time of food additives induction. 
In connection, the food-stuff additives (flavor and colourant) treatments decreased the total lipid and total cholesterol contents in both blood and liver of inducted rats Table- 2 . Synthetic chocolate colourant was more effective than the synthetic chocolate flavor on the lipid or cholesterol patterns, but chocolate mixture induction had the highest effect. In general, the present results were confirmed by the studies of Abdel-Rahim et al. ${ }^{40}$ and Amin et al. ${ }^{37}$ who found that both synthetic food flavors and colours reduced the level of lipid and cholesterol in blood and liver. Our results are contrary with the results obtained by Abou El-Zahab ${ }^{4}$ and Himiri et $a .^{41}$, who observed significant increase in serum triglycerides of rats treated with synthetic colour (tartrazine) and chocolate colour A and B that containing tartrazine and carmoisne. Also, Hansen et al. ${ }^{42}$ and Abdel-Rahim et al. ${ }^{40}$ observed that an increase of thyroid hormone secretions were inducted by synthetic food colourants or flavorings treatment. Thyroxin stimulated the lipolysis, glycogenolysis and gluconeogenesis processes. Moreover, the elevations of blood sugar and reductions of liver glycogen, total lipid and total cholesterol of blood and liver reveled to the enhancement of these processes.

The administration of either synthetic flavor, colourant or flavor and colour mixture caused marked increase in the level of the four test blood compounds (hemoglobin, bilirubin and thyroid gland). However, the increase in the total hemoglobin, total bilirubin, $\mathrm{T}_{4}$ and $\mathrm{T}_{3}$ in blood of inducted rats was more pronounced in case of chocolate mixture than the individual synthetic chocolate flavor or chocolate brown FB. It may be pointed out that the indicated effect occurred irrespective of the treatment of synthetic food-stuff additives. However, the total hemoglobin, total bilirubin, $\mathrm{T}_{4}$ and $\mathrm{T}_{3}$ contents of blood subjected to synthetic food-additives induction can be arranged in the following increasing order, synthetic chocolate flavor and colourant mixture, synthetic chocolate brown FB and synthetic chocolate flavor. The present results are in agreement with the observation of Hansen et al. ${ }^{42}$ and Abdel-Rahim et al. ${ }^{30}$ who found that synthetic food colourant or flavor increased the total hemoglobin total bilirubin and thyroid hormones content in rats' blood. The alteration in thyroid activity may have resulted from alters in the pituitary gland activity as a consequence of the stressing effect of food additives. But the etiology of this state has not been clarified, yet.

Finally, it can be suggested that the higher and residual effect of the synthetic food-stuff additives might be referred to their uptake and accumulation by the body.

\section{Conclusion}

It can be concluded that all food additives of synthetic brown chocolate treatments significantly enhanced the transaminases (GOT and GPT) activity and the protein content in blood and liver of inducted rats. $\mathrm{T}_{4}$ and $\mathrm{T}_{3}$ in blood of inducted rats were significantly increased. The alteration in thyroid activity may have resulted from alters in the pituitary gland activity as a consequence of the stressing effect of food additives. $\mathrm{T}_{4}$ and $\mathrm{T}_{3}$ stimulated the lipolysis, glycogenolysis and gluconeogenesis processes, which decrease total lipid and total cholesterol of blood and liver and also decrease liver glycogen and increase blood glucose in treated rats. Hemoglobin and bilirobin were also increased in blood of synthetic brown chocolate treated rats. All these alteration were observed much greater by chocolate mixture than by chocolate flavor or colour. Also, liver was more affected than blood.

\section{ACKNOWLEDGEMENTS}

The authors extend their appreciation to the Deanship of Scientific Research at King Saud University for funding the work through the research group project No RGP-VPP-130.

\section{REFERENCES}

1. I.F. Gaunt, F.M.B. Carpanini, P. Grasso, I.S. Kiss and S.D. Gangolli, Food Cosmet. Toxicol., 10, 17 (1972).

2. W. Herbst and K. Hunger, Industrial Organic Pigments: Production Properties, Applications, Verlagsgesellschaft MBH, Germany, edn 2 (1997).

3. G.M. Hassan, Arab J. Biotechnol., 13, 13 (2009).

4. H. Abou-El-Zahab and Z.G. El-Khyat, Pro-Boll Chemical Farm, 136, 615 (1979)

5. G.E. Helal, A.M. Zaahkouk and A.H. Mekkaway, J. Hosp. Med., 1, 103 (2000).

6. P. Mpountoukas, A. Pantazaki, E. Kostareli, P. Christodoulou, D. Kareli, S. Poliliou, C. Mourelatos, V. Lambropoulou and T. Lialiaris, Food Chem. Toxicol., 48, 2934 (2010).

7. A. Moutaouakkil, Y. Zeroual, F. Zohra Dzayri, M. Talbi, K. Lee and M. Blaghen, Arch. Biochem. Biophys., 413, 139 (2003).

8. Food and Drug Administration,US Department of Health and Human Services. Food Ingredients and Colors, International Food Information Council (IFIC) and US Food and Drug Administration, Nov. 2004, revised April (2010).

9. A. Das and A. Mukherjee, Int. J. Hum. Gen., 4, 277 (2004).

10. C. Madsen, Environ. Toxicol. Pharmacol., 4, 115 (1997)

11 M. Tripathi, S.K. Khanna and M. Das, Food Contr., 18, 211 (2007).

12. F.M. Clydesdale, Crit. Rev. Food Sci. Nutr., 33, 83 (1993).

13. J.F. Borzelleaca, J. Hallaga and C. Resse, Food, Drug and Cosmetic Colours: Toxicological Consideration, ACS Symposium Series, 234, 311 (1983)

14. A.E. Bawazir, J. Evol. Bio. Res., 4, 13 (2012).

15. M.O. Elhkim, F. Héraud, N. Bemrah, F. Gauchard, T. Lorino, C. Lambré, J.M. Frémy and J.-M. Poul, Regul. Toxicol. Pharmacol., 47, 308 (2007).

16. W. Lane-Petter and A.E.G. Pearson, Dietary Requirements, In: The Laboratory Animal Principles and Practice, Academic press, London and New York, p. 142 (1971).

17. FAO/WHO Toxicological Evaluation of Some Food Additives, Food Agricultural Organization of the United Nations and World and Health Organization, Rome (1974).

18. A.M. Astoor and E.J. King, Biochem. J., 56, 125 (1954).

19. B.N. Premachandra and I.I. Ibrahim, Clin. Chim. Acta, 70, 43 (1976).

20. I.J.Chopra, R.S. No and R. Lam, J. Lab. Clin. Med., 80, 729 (1972).

21. P.K. Joseph, A. Shauma and H. James, Powl. Clin. Chem., 18, 199 (1972).

22. A.J. Chaurchami, W. Miller and J.D.B. Stein, Clin. Chem., 5, 609 (1959).

23. E. Rerup and S. Lundquist, Acta Pharmic. Lox., 25, 47 (1967).

24. L. Jendrassik, and P. Grof, Bilirubin Determination of Bilirubin in Blood Serum, edn. 7, Bray's Chin. Lab. Methods. Published by John D. Dauer, Philip, C. Ackermann and Gelson Toro-Sand Louis (1968), pp. 357 (1953).

25. J.Y. Dacie and S.M. Lewis, Measurement of Hemoglobin Cyanmethemoglobin Method; In: Practical Hematology, Churchill Livingstone Edinburgh. London and New York, edn 5, pp. 32 (1975).

26. R. Henry, Determination of Total Protein in Blood Serum, Clinical Chemistry Principles and Techniques. Harper Row, New York, pp. 182 (1964).

27. S. Ritman and S. Frankel, Am. J. Clin. Pathol., 20, 56 (1957).

28. D.M. Snedecor and W.G. Cochran, Statistical Methods, The Iowa Univ. Press, Ames, Iowa, USA (1967).

29. I.F. Gaunt, P.G. Brantom, P. Grasso and I.S. Kiss, Food Cosmet. Toxicol., 11, 375 (1973) 
30. E.A. Abdel-Rahim, Y.A. Ashoush, A.S. Afify and E. Hewedl, J. Agric. Res., 13, 2001 (1988).

31. F. De Ritis, Minerva Med., 49, 1757 (1958)

32. S. Sherlock, Diseases of the Liver and Billary System, Blackwell, Scientific Publishers, Oxford, edn 5 (1975).

33. S. Sharma, R.P. Goyal, G. Chakravarty and A. Sharma, J. Asian Exp. Sci., 19, 93 (2005).

34. K.A. Amin, H. Abdel Hameid II and A.H. Abd Elsttar, Food Chem. Toxicol., 48, 2994 (2010).

35. G.E. Helal, A.M. Zaahkouk and A.H. Mekkawy, Egypt. J. Hosp. Med., 1, 103 (2000).

36. H.A. Mekkawy, M.G. Ali and A.M. El-Zawahry, Toxicol. Lett., 95, 155 (1998).
37. K.A. Amin, H. Abdel Hameid II and A.H. Abd Elsttar, Food Chem. Toxicol., 48, 2994 (2010).

38. H.G. Hers, Adv. Metab. Disord., 1, 2 (1964)

39. W.A. Wood, Annu. Rev. Biochem., 35, 521 (1966).

40. E.A. Abdel-Rahim, Y.A. Ashoush, A.S. Afify and E. Hewedl, J. Agric. Res., 14, 557 (1989).

41. I. Himiri, S. Bellahcen, F. Souna, F. Belmekki, M. Aziz, M. Bnouham, Z. Berkia, H. Mekhfi and E. Saaluri, Int. J. Pharm. Pharmaceut. Sci., 3, 159 (2011).

42. W.H. Hansen, K.J. Davis, S.L. Graham, C.H. Perry and K.H. Jacobson, Food Cosmect. Toxicol., 11, 535 (1973). 